Dynamic interactions in contentious episodes: social movements, industry and political parties in the contention over Heathrow's Third Runway

Eugene Nulman

Centre for the Study of Social and Political Movements, School of Social Policy, Sociology and Social Research, University of Kent, Canterbury, UK

SSPSSR, Cornwallis North East, University of Kent, Canterbury, Kent CT2 7NF

01227823072

E.Nulman@kent.ac.uk 


\title{
Dynamic interactions in contentious episodes: social movements, industry and political parties in the contention over Heathrow's Third Runway
}

\author{
While the literature on dynamics of contention has proliferated, its focus on \\ movement onset, mobilization and outcomes could be used to understand \\ interactions between actors during episodes of contention. While McAdam et al. \\ (2001) acknowledge the importance of these interactions, more insight is needed \\ into what shapes these relations and how they change over time. Here I attempt to \\ test the dynamic model as it pertains to interactions, utilizing the case of the \\ proposed third runway at Heathrow airport, which included a variety of \\ environmental campaigners, powerful corporations, political actors and parties, \\ and a countermovement. I break down the campaign into phases that represent the \\ predominant interactions between actors, and seek to understand the process of \\ phase changes using a process-tracing approach. The findings highlight the \\ importance of cognitive mechanisms over objective factors. However, \\ explanations offered by more static models retain some explanatory power and \\ therefore should not be discarded altogether.
}

Keywords: aviation policy; climate change; social movements; Heathrow; policy change; dynamics of contention; interactions

\section{Introduction}

The environmental movement, like many social and political movements, seeks to change the behaviour of an array of actors ranging from state and business institutions to individuals. Various interactions take place between the movement and such actors. Movement actors may, for example, focus their sights on individuals but interact with them in a variety of ways: shaming them for specific actions; persuading individuals through rational discourse or through affective means; making individuals increasingly aware of alternative options to environmentally damaging consumption or practices through movement communication or through intermediary sources such as news media. These and other forms of interaction can also be found in the literature on movement interactions with corporations and industries (e.g., den Hond and de Bakker 2007; Schneiberg et al. 2008; Schurman 2004). While these separate forms of interaction have been described elsewhere, the literature has often neglected their changing nature in the presence of dynamic strategic and tactical manoeuvres and reinterpretation of information. Early 
social movement theories generally reinforced static conceptualizations of actor interactions and movement processes (e.g., rational choice, Olson 1965; resource mobilization, McCarthy and Zald 1977; and bureaucratization, Michels 1915), which underpinned much of the subsequent literature. These theories produced models of interaction that relied heavily on a single type of mechanism.

More recent innovation in social movement theory has expanded our understanding of the dynamic interactions between groups. McAdam, Tarrow and Tilly's (2001) now oft-cited Dynamics of Contention (DOC) encouraged scholars to move away from considerations of objective and static theoretical modelling towards social constructionist perspectives that explore complexities within and between actors. Part of their thesis highlights: that 'participants in contentious politics constantly manipulate, strategize, modify, and reinterpret' (ibid. 56); that 'single movements are embedded in different contexts of contention and interact with other actors in an iterative dance of mobilization and demobilization, identity formation and innovative collective action' (ibid. 66); and that 'All politics - transgressive as well as contained - operates though interaction involving members, challengers, and subjects' (ibid. 50). Similar dynamic processes regarding interactions between actors can also be found in works on strategic action fields (see Fligstein and McAdam 2011). More recent work following this approach has illuminated understanding of relations between actors (e.g., Heaney and Rojas 2011) but few studies focus on the dynamic interactions between industry, activists, and policymakers throughout a campaign, particularly concerning the mechanisms that shape these interactions. Instead, most examinations of the mechanisms discussed in DOC regard movement onset and outcomes, despite the importance that McAdam et al. place on relations between actors.

Mechanisms seek to explain how processes are causally linked, allowing us 'not only to describe what is likely to happen but also to explain why it is likely to happen' (Hedström and Swedberg 1998, 10). In order to understand the dynamics of contention, DOC utilized a typology of mechanism types: environmental (external), cognitive (interpretive), and relational (McAdam et al. 2001, p. 25-6). While several specific mechanisms that were highlighted in the text were a result of interactions between two or all three mechanism types, the authors wanted to emphasize the role of relational mechanisms. However, they acknowledged that 'any adequate theory of contention will have to integrate environmental, cognitive, and relational mechanisms far more firmly than this volume has' (ibid., p. 344). Here I set out to accomplish three interlinked tasks that build on and test the $D O C$ approach.

First, in addressing McAdam et al.'s concern, I seek to 'more firmly' integrate the mechanism types described in DOC. Second, whereas McAdam et al., and others (e.g., Heaney and Rojas 2011), applied these types of mechanisms to understanding changes to mobilization and outcomes, I use these mechanisms to explore the changes in relations between actors in the course of a campaign. Specifically, I examine a campaign that attempted to influence contemporary environmental policy, moving away from the more historical examples found in $D O C$ and applying the concepts to modern contentious politics. Third, by focusing on a 
movement with a variety of actors I have the chance to observe more interactions, providing a more nuanced picture of interactions. A sustained environmental campaign is a particularly suitable case for such an exercise because of the environmental movement's consistent claimsmaking against both private business institutions and government bodies (Pellow 2001; Walker et al. 2008), often simultaneously. Specifically, the campaign against expansion of the UK's principal hub airport, Heathrow, was selected because of: its large number and variety of actors, including state, business, movement and countermovement actors; the decentralized and loosely networked nature of movement actors, and; its extended timeframe.

From 2001, when aviation industry officials publically supported an additional runway at Heathrow, a protracted battle ensued over its construction. Local residents had already spent decades dealing with continuous expansion at the airport (Interview, Labour MP, John McDonnell 21 June 2012). In the case of the third runway, national ENGOs and direct action activists joined local residents in opposing the expansion. They battled the lobbying power of the aviation industry, which had dictated aviation policy to both the Labour and Conservative parties for decades (ibid.; Stewart 2010). Both parties supported the third runway until 2008, when the Conservatives effected a U-turn on the issue, shocking the industry, commentators, and many of the party's supporters. In the attempt to gain marginal seats in the western suburbs of London, the Conservatives were competing for votes against the Liberal Democrats, the third largest party, who were staunchly opposed to the runway on environmental grounds. After the 2010 election resulted in a Conservative and Liberal Democrats coalition government, plans for the expansion of Heathrow, approved by the outgoing Labour government during its final months, were abandoned.

Throughout the campaign, political parties, local community members living near the airport, local and national environmental organizations, and businesses had expressed their opinions on the issue and positioned themselves in relation to others. The key actors involved included: the three largest political parties, including rebels in the Labour party who are opposed to the expansion; the aviation industry,especially the airport operator BAA (British Airports Authority, now named Heathrow Airport Holdings), and the airline, British Airways, for which Heathrow is its main base; the campaigning network, which expanded throughout the course of the campaign, with local community group HACAN ClearSkies at its core; and local and national publics. Their voices changed tone and message and were directed toward different actors over the course of the contest. Because the highly contested issue involved a wide variety of actors over a significant period of time and included politically influential businesses, the campaign represents an excellent case through which to examine the dynamics of interaction between actors.

\section{Methodology}

In order to accomplish the tasks set out above, I employ a process-tracing approach in which 'the researcher examines histories, archival documents, interview transcripts, and other 
sources to see whether the causal process a theory hypothesizes or implies in a case is in fact evident in the sequence and values of the intervening variables in that case' (George and Bennett 2004, p.6). By gathering detailed data using a variety of sources, researchers can unpack contentious episodes and pinpoint causal-process observations, or 'insight[s] or piece[s] of data that provide[ ] information about context, process, or mechanism, and that contribute[ ] distinctive leverage in causal inference' (Brady and Collier 2004, pp.227-8).

By focusing on a campaign that lasted several years we can gather a wealth of data about the various actors. In addition, we can segment the campaign into phases of interaction. Interaction phases are marked by the overarching relations between actors, primarily between movement, government and industry actors. While interactions vary between these actors within a phase, a pattern of interaction can be observed. Phase changes occur when those overarching interactions shift and a new pattern of interactions occurs.

Below is a brief history of the Heathrow third runway campaign, broken up into phases of interaction. This will be followed by an investigation into the mechanisms that explain the changes of phases, allowing us better to understand the processes that occur during such campaigns.

\section{History of the Campaign and Interaction Phases}

\section{Government mediation (1995-2000)}

On 16 May 1995, the public consultation for a proposed $5^{\text {th }}$ terminal (T5) at Heathrow airport commenced. The aviation industry advocated T5 as a means to accommodate additional passengers. The opposition to T5 grew largely among local community and council members who viewed the government's formal consultation process as the primary means to resolve conflicts between the aviation industry's desire to expand the UK's hub airport and the communities' desire to contain the level of noise and air pollution and preserve community spaces. Local organizations took the public inquiry seriously, using their resources to engage with the consultation process. Although it was well understood that BAA had applied for planning approval for T5, and that the terminal would be the home of British Airways, it was the government that would make the decision to approve the development, and it was believed that with enough mobilization around the consultation the campaigners' interests would trump those of the aviation industry. The consultation for T5 was the longest in UK history, ending 17 March 1999 (Butcher 2014).

The inquiry also became the field of contestation between competing arguments. Campaigners used the platform to attack the industry's statements in their submissions to the inquiry (e.g., Friends of the Earth 1997). HACAN, the largest community organization actively opposed to T5, represented over 7,000 community members, and focused on the single largest issue of contestation for the local community: noise pollution (Stewart 2010, p.50). At the first 
day of the inquiry, their chairman Dermot Cox declared: 'We have every confidence that the Inquiry will make a full and balanced assessment of the important issues before it' (HACAN 1995). By the end of the inquiry, over 700 witnesses had testified, 5,900 inquiry documents were produced (Doherty 2008, p.47), and 27,000 written representations were collected (Graham $2008, p .112)$. Due to the number of responses, it took nearly two years after the inquiry to complete the inspector's report, which was published in December 2000. It recommended that the terminal be approved with some modifications. On 20 November 2001, the Labour Government approved the development of the terminal, albeit with some protections for local residents.

The subjective positioning of the consultation process as constructive was conducive to the maintenance of cordial relations between the actors during this lengthy first phase. Only after the campaign reconceptualised the relations of other actors, principally the state and industry, did the campaign's relations with these actors change.

\section{Displaying discontent (2001-2004)}

The failure to stop $\mathrm{T} 5$ from gaining approval altered the conflictual relationship between campaigners and the aviation industry. The government was no longer seen as an objective mediator (cognitive mechanism). Instead, campaigners viewed the government as having been infiltrated by the 'aviation lobby' and the industry's interests (Stewart Interview, 9 December 2011). It was only then that campaigners engaged with the industry in other ways. First, this led to important shifts in the campaign, starting with the conjoining of two local anti-expansion groups (HACAN and ClearSkies) under the leadership of John Stewart, who had played a key role in the UK anti-roads movement in the 1990s by helping to establish ALARM, a network of local anti-roads campaigns (Rootes 2013, p.111, n.13). Under Stewart's leadership, the group opposed the consultation and inquiry process. In discussing his position on the consultation process prior to his role at HACAN ClearSkies, Stewart stated: 'It gives a veneer of respectability that they've consulted the public. To be quite honest...they should abolish them [Public Inquiries]. That's the starting point I had'. (Interview, 9 December 2011).

It was not, however, only the local leadership that changed campaign-industry relations, but the process of the inquiry itself. Friends of the Earth (FoE) had noted toward the end of the inquiry that conflicts of interest were present. FoE argued that BAA witnesses were also government officials and that 'the Government is systematically biased in favour of BAA and T5' (Friends of the Earth 1998). As the threat of the third runway grew, and with both major parties supporting the third runway, the sense that the inquiry was an ineffective tool gave leverage to Stewart, who was strongly opposed to the consultation and inquiry process. During this phase, the campaign expanded, networked and formed links with local politicians.

In 2002, it was estimated that 100 houses would be demolished (the estimate was later raised to 400), which helped to mobilize community residents to oppose the runway on grounds that airport expansion would uproot homes and devastate communities. These residents began 
displaying their discontent with orange stickers and signs reading 'No Third Runway', particularly during a two-day exhibition organized by the Department for Transport (DfT) to inform the public of the impacts of the proposed expansion (Geoghegan 2002a). The following month, 600 campaigners from various groups protested in Parliament Square (Geoghegan 2002b), and later 300 protested in Turnham Green (chiswickw4.com 2002). Others voiced their opinion against further expansion, including West London Friends of the Earth (Haifacree 2001) and London Wildlife Trust (Saunders 2004), and protests continued in 2003-4 (ibid.; HACAN ClearSkies 2003b). In October 2003, during the actual construction of T5, eight activists climbed atop a crane at the building site and held a protest for several nights (Richmond \& Twickenham Times 2003). The following month, a road leading to the construction site was blockaded by protesters (HACAN ClearSkies 2003a).

This phase saw organizations build links around the issue of the third runway, but their actions often revolved around the government or the local community, not the industry. Industry was seen as profit-seeking but was not the central target of protesters who preferred to build strength by informing local residents and demonstrating to signal opposition to government policies following the disappointment of the T5 inquiry process. Campaigners engaged simultaneously in mobilizing and demonstrating while government and industry had little to fear, framing the campaigners as NIMBY ('Not in My Backyard') protesters.

\section{Countermobilisation \& competition (2005-2006)}

In March 2005, Labour Prime Minister Gordon Brown announced that British Airways chief Rod Eddington was to be made a special advisor on transport. HACAN ClearSkies (2005a) commented that this move 'cements links between the aviation industry and government'. When industry was seen as directly involved in political decision-making, campaigners retaliated. At the end of the month, campaigners arrived at Eddington's house at 5a.m., playing loud aircraft noise simulating that heard by local residents (HACAN ClearSkies 2005b). However, direct confrontation with the industry remained minimal during this phase. Instead, after the aviation industry started countermobilizing, competition occurred around public opinion, local concerns and policy positions of political parties (Soley 2005). The industry perceived that the campaign had successfully mobilized opposition (and in a way that threatened its interests) during the second phase (cognitive and relational mechanism) and formed a coalition - Future Heathrow with unions and business associations to campaign for the third runway ${ }^{1}$. Its launch in May 2005 was met with protests (SchNEWS 2005). With local opposition seeming strong, Future Heathrow appointed as campaign director Clive Soley, a former Labour MP and a resident of west London.

This competition led to increased protests around the proposed runway more generally, particularly by a group of residents who joined together to form No Third Runway Action Group

${ }^{1}$ Although BAA was not officially part of Future Heathrow, the pressure group's offices were in a BAAowned building. When pressed, BAA acknowledged that Future Heathrow was 'aligned to some of our key stakeholders' (NoTRAG 2005). 
(NoTRAG). In November 2005, EarthFirst! became involved, joining local campaigners in protesting at an aviation conference (Rikki 2005). Plane Stupid, an organization of nonviolent direct action activists focusing on the climate change impacts of aviation, formed around this time. On 3 April 2006, it protested at BAA headquarters.

Climate change, a new frame brought to the campaign by Plane Stupid, forced the industry into a competition over wider public opinion as it began to resonate with a wider audience. BAA chief executive Mike Clasper (2006) wrote to The Guardian to 'dispel a couple of myths' about the impact of aviation on climate change, stating: 'When people living near airports argue against expansion, for understandable local reasons, they should not hide behind bigger arguments about climate change'.

This frame expansion (see Boudet 2011) produced a scale shift (see McAdam et al. 2001, p. 332-4) in the campaign (see Rootes 2013), which fostered additional tit-for-tat competition. After Future Heathrow argued that business was on their side, HACAN publicized a Chamber of Commerce survey showing that $78 \%$ of firms opposed expansion at Heathrow (HACAN ClearSkies 2006). When Future Heathrow made arguments about Heathrow expansion, HACAN worked to publicize counterarguments (HACAN Clearskies n.d.). The efforts of Plane Stupid, increased resources, and the introduction of the climate change frame into the campaign led to the next phase of contentious interaction.

\section{Direct confrontation and convergence (2007)}

Unlike previous phases, in 2007 direct confrontation between the campaign and the industry came to the fore. The first instance was Greenpeace's 'impromptu ticket exchange booths' set up in the airport, which offered British Airways passengers checking into domestic flights the opportunity to exchange their tickets for climate-friendlier train tickets (Greenpeace 2007). That same month, protesters, including residents and Plane Stupid members, carried a bed with two figures on top from the flat of BAA Chief Executive Stephen Nelson to DfT headquarters under the slogan 'DfT in bed with BAA' (HACAN ClearSkies 2007). Plane Stupid activists then protested the $60^{\text {th }}$ birthday of Heathrow airport by chaining themselves to the entrance of BAA (Plane Stupid 2007a).

A change in relations was emerging. As a result of ongoing resistance to changing policy positions and new information, campaigners reinterpreted the government's relationship with industry (cognitive mechanism). They saw the government as having been influenced by the industry to the point that their interests were one and the same. This convergence of interests led to moments of converged protests, protests targeting both the aviation industry and the government with claims of collusion. In addition, the campaign had expanded to include confrontational action as the resources of direct action organizations grew.

At that time it was known that the Camp for Climate Action (Climate Camp) had set its sights on Heathrow. Climate Camp was a loosely organized group that held annual week-long 
protest camps in different locations to protest climate change (see Schlembach, Lear et al. 2012; Saunders and Price 2009). In the run up to their 2007 camp, the Camp for Climate Action employed democratic decision-making processes and open meetings to decide where the protest camp would take place. After intense debate, participants were convinced by Plane Stupid activists to hold the camp at Heathrow. The perceived threat of this protest, which was to be held on or around BAA property near the airport, led BAA to seek a legal injunction. Confronting the protesters in court, BAA sought the injunction on the grounds that the protest could result in disruption at the airport. This initial injunction pertained to organizations that supported the campaign and their members, which included national groups such as the Royal Society for the Protection of Birds (RSPB), Campaign to Protect Rural England (CPRE), FoE, and the National Trust. In total the injunction would have banned over 6 million people from Heathrow Airport and a range of other nearby locations (Stewart 2010, p.30). This overreach was quickly acknowledged by the court, with the judge herself a member of 'no fewer than three of these groups' (Murray 2007, 24). The injunction was scaled down to include only Plane Stupid members, HACAN chair Stewart and NoTRAG chair Geraldine Nicholson (Stewart 2010), but not before the media latched onto the story. Nevertheless, it was a partial victory for BAA, leading Climate Camp to alter plans for the location of its protest camp so that those named in the injunction could participate.

Once the protest camp arrived at Heathrow, it also directly confronted its opposition. As part of the 24-hour mass action that represented the climax of the camp, several demonstrative actions against the aviation industry were held, including a march to Heathrow's main administrative building, a protest at BAA's Heathrow Academy, and a blockade of the British Airways World Cargo depot (Indymedia 2007). Later in the year, protesters interrupted a speech by Transport Secretary Douglas Alexander at an airline industry conference (Plane Stupid 2007b) and interrupted 'The Future of BAA' meeting held by the Transport Select Committee, arguing that the government was 'colluding with BAA to concrete over public debate' (Plane Stupid 2007c).

\section{Divergent approaches (early- to mid-2008)}

By 2008, no clear relationship could be observed between campaigners, policymakers and the industry. Instead, the variety of actors within the campaign began to fully embrace the coalition's motto as developed by Stewart: 'unity of purpose, diversity of tactics' and had various interactions with other actors. The campaigners' increased support (relational mechanism), a shift in public opinion and issue salience (environmental mechanism) and the view that momentum was building (cognitive mechanism) affected their interaction as compared with the previous phase.

Different campaigning groups became more involved and interacted with policymakers and industry representatives in divergent ways. Previously, campaigners relied on politicians opposed to the runway to work within their parties to push the issue. Most prominent was Labour MP John McDonnell who had opposed Heathrow expansion for decades, raising the issue, in his 
own words, 'on every opportunity I possibly could and be in their face about it, lobby ministers and work as hard as I could behind the scenes' (Interview, John McDonnell 21 June 2012). Conservative MP Justine Greening and prospective Conservative candidate Zac Goldsmith were doing the same for the Conservative Party (Personal Correspondence, Justine Greening 17 September 2014; Personal Correspondence, Zac Goldsmith 15 September 2014). By 2008 these relations changed and campaigners were more direct in their engagement with policymakers, even while indirect approaches continued (e.g., Stewart 2010,18).

The relationship with the aviation industry was also varied. In February, FoE Executive Director Tony Juniper called on Virgin Airlines founder Richard Branson, who was outspoken in his concerns regarding climate change, to 'ask right away...that ministers shelve their insane plans to construct a third runway at Heathrow' (Juniper 2008). Meanwhile, Plane Stupid continued to pursue the convergence logic when its activists climbed onto the roof of the Houses of Parliament displaying a sign reading 'BAA HQ' (George 2008), and others protested industry targets directly (e.g., Greenpeace 2008b).

In addition, campaigners took actions to influence the wider public, raising awareness through media attention by holding a flashmob (and raising concerns over possible disruption) inside Terminal 5 during its grand opening (Greenpeace 2008c; Stewart 2010, 36), organizing a Make-a-Noise Carnival where approximately 3,000 people attended and together spelled out 'NO' with human bodies along a field (Greenpeace 2008d), and spread messages opposing the third runway using 'clean graffiti' (Greenpeace 2008a).

\section{Repoliticized relations (mid-2008 - mid-March 2009)}

Campaign and industry strategies qualitatively changed in mid-2008 when, in June, the Conservative Party, led by David Cameron, decided to publically oppose the third runway, which represented a major policy U-turn (relational mechanism). The Conservative Party U-turn itself was predicated on a 'greening' strategy (cognitive mechanism), attempting to draw in young voters and compete with the Liberal Democrats (environmental mechanism) on the environmental issue (see Nulman 2015).

Stewart, who had been forewarned by local officials about the likely U-turn (Interview, John Stewart 9 December 2011), strategized to make such a U-turn more palatable for Conservatives. HACAN and NoTRAG commissioned a report which examined the aviation industry's claim (Interview, BAA Representative 4 July 2012) that Heathrow expansion was vital to the British economy. The report concluded that previous economic studies used by the government were based on best case scenarios and contained other methodological flaws (Boon et al. 2008). The report showed, in effect, that Heathrow expansion was not necessary for economic growth in the UK, and targeted the aviation industry's economic argument for expansion while at the same time providing an economic basis on which political parties could stand against the runway with diminished fear of repercussions from the business and finance sectors and pro-business voters. 
The Conservative Party U-turn led to a refocusing of the energies of both industry and campaigners onto policymakers. Industry representatives became more proactive in lobbying the government and attacking the Conservative Party, while campaigners moved to support the Conservatives and increased protest against the Labour government. For campaigners, there was a general relaxation of direct antagonism toward the industry, but the industry itself became more antagonistic. Having previously felt assured that the pro-business Conservative Party would take its side on ideological grounds, the industry harangued the Conservatives about their policy U-turn. British Airways Chief Executive Willie Walsh was said to have publically 'bad mouthed' Cameron during a conference (Milmo 2008a), and British Airways and BAA later reproached the Conservatives for calling for a railway alternative for the third runway (Milmo 2008b). The industry also attacked campaigners and their efforts to appeal to the Conservative Party (Milmo 2008c). Walsh (2008), realizing the importance of the climate change argument that was developed by the campaign during the direct confrontation and convergence phase, also wrote an op-ed for The Guardian arguing that stopping the construction of a third runway would not 'reduce absolute emissions one iota'.

While the industry attacked the Conservatives and campaigners, campaigners focused their efforts on the Labour government. In one action, a member of Plane Stupid attempted to superglue his hand to the jacket of Labour Prime Minister Gordon Brown while concealing that this was being recorded via Skype. HACAN and NoTRAG later organized a rally at Central Hall, London to mark the end of the government consultation for the third runway, filling it to capacity with approximately 3000 in attendance, including politicians such as Liberal Democrat leader Nick Clegg and Labour MPs Anne and Alan Keen (Stewart 2010, 35; Heathrow Consultation Rally 2008). Likewise, just days before the government was set to make its decision to grant the planning application, MPs joined protesters in a 'sit-in dinner at domestic departures' at Heathrow (Interview, Tamsin Omond, Climate Rush, 17 July 2012). The following day, Greenpeace, celebrities and politicians came together and purchased a one-acre plot of land on the site of the proposed runway with the intention of dividing it up into smaller plots of land and selling it off. This 'Airplot' was seen as a way of delaying the third runway by forcing the government to issue compulsory purchase orders in order to seize it (Hilson 2010), but it also worked to attack the Labour Party as Liberal Democrat leader Nick Clegg was one of the owners and David Cameron 'agreed to have a tree planted on the land in his name' (Greenpeace 2010).

The Conservatives' U-turn and the campaign's focus on Labour, including being lobbied by HACAN via the firm Cogitamus (Stewart 2010, 33), appeared to have an impact. By November, criticism of the expansion policy within the Labour Party had grown, with environment minister Hilary Benn and energy and climate change minister Ed Miliband taking the lead. Nevertheless, the government approved the runway, although concessions were made regarding its use. The following day Campaign against Climate Change (2009) led a protest march on Downing Street with hundreds in attendance under the banner 'the green future versus 
the Brown past'. Soon after, another flashmob was held at Heathrow, this time focusing on Transport Secretary Geoff Hoon (Stewart 2010, 42).

While opposition political parties supported the campaign's position, the Labour government refused to budge, although rebels in the party voiced their concerns. Amidst protests at Westminster, the Conservatives used their opposition day in the House of Commons to hold a symbolic vote against the third runway, and some Labour MPs resigned their junior ministerial positions in order to vote against their government (Stewart 2010, 41). The following months saw several demonstrations including a protest at Downing Street, the interruption of speeches by government ministers, and the throwing of a pie into the face of Business Secretary Lord Mandelson amid reports he had met with the head of BAA's public relations firm (HACAN ClearSkies 2009). Legal challenges also started at this time, focusing on the Labour government's consultation process (Vidal 2009) and failure to consider the impact of the third runway on the new climate change targets imposed by the Climate Change Act 2008 (WWF-UK n.d.). This legal challenge was launched just a few weeks after the government admitted that BAA would not be able to make a formal application for the third runway prior to the 2010 general election (Milmo 2009a).

\section{Festive irritation (late-March 2009 - 2010)}

The next phase of campaign-industry relations began with the government's acknowledgement that the 2010 general election would determine the outcome of the third runway (relational mechanism). This allowed campaigners to breathe a sigh of relief because the parties opposing expansion were polling more strongly than was Labour (environmental mechanism) and fissures in the Labour Party were widening (relational mechanism). Later in 2009 BAA announced that it would not apply for planning permission for the third runway if the Conservative Party formed the next government (Gourlay and Ungoed-Thomas 2009).

Campaigners, sensing a likely but uncertain victory (cognitive mechanism), maintained their opposition but in more festive ways, often ignoring industry targets altogether. Greenpeace organized hundreds of people to form a large 'No' on the ground at the Glastonbury festival (Lewis 2009) and NoTRAG held a picnic on the Airplot (NoTRAG 2009). Climate Rush held a low-carbon horse-and-cart tour at Heathrow (van der Zee 2009), and Plane Stupid activists, joined by a Heathrow resident, 'hijacked' a table reserved for Virgin Atlantic at a public relations awards ceremony (Plane Stupid 2009a), later also protesting at the Architect of the Year presentation by presenting a fake award to the potential designers of the third runway (Plane Stupid 2009b). The industry was less visible during this time, but Willie Walsh did urge the Conservative Party to rethink its U-turn on the third runway, calling it the 'biggest mistake ever' (quoted in Milmo 2009b).

The May 2010 general election resulted in a Conservative-Liberal Democrat coalition government. Since both parties had committed in their election manifestoes to reversing the 
outgoing Labour government's approval of the third runway, the project was officially abandoned.

By October 2011 the Labour Party, now in opposition and with Ed Miliband as leader, also took the third runway off its agenda. Although the third runway has since remained rejected, the industry continues to lobby for further expansion at Heathrow and at airports elsewhere. While there have been discussions within the coalition government about reconsidering the third runway, the leadership has insisted that the government 'explore all options for maintaining the UK's aviation hub status, with the exception of a third runway at Heathrow' (Chancellor George Osborne quoted in Stewart 2012; my emphasis).

Nevertheless, in 2012 the government established an independent body, the Airports Commission, to investigate the need for airport expansion in the UK. This produced an interim report in December 2013 that recommended consideration of three alternatives: a second runway at London's Gatwick Airport; an extension of one of Heathrow's existing runways to effectively enable it to be used as two independent runways; and a new, third runway at Heathrow.

Following the release of the report, John Stewart warned that 'the scale of the opposition will be so great that we believe that [the proposals] are politically undeliverable' (quoted, AirportWatch 2013), while 'At Plane Stupid HQ, we have been spending the week reminiscing about occupying runways and the houses of parliament, while wiping the dust off our D-locks. Thousands of climate change protesters are on alert. Here we go again.' (Plane Stupid 2014).

\section{Findings and Discussion}

The complexity of each shift in phase highlights the interpretive element of interaction between actors. The cognitive mechanism type was important in every change of phase, often coupled with one or two other mechanism types ${ }^{2}$. Objective changes occurred from shifted alliances, heightened issue salience among the general public, increased party competition, and the results of polls of voting intention. However, these needed to be interpreted before they proceeded to affect actor interactions.

The shift to a second phase was specifically prompted less by the failure to successfully stop the $5^{\text {th }}$ terminal using the consultation process and more by the advent of new leadership in the wake of that campaign's failure. The new leadership of the local organization HACAN ClearSkies interpreted the consultation process as unresponsive, but this was consistent with the predisposition of the group's Chair, Stewart, long before the failure of the campaign against the $5^{\text {th }}$ terminal. However, the failure of that campaign made Stewart's argument against institutionalized approaches to stopping the third runway more palatable to other campaigners.

\footnotetext{
${ }^{2}$ While $D O C$ also examined particular mechanisms within each mechanism type, its authors' focus on relational mechanisms and on explaining mobilization and outcomes meant their specific mechanisms were often uninvolved in understanding actor interactions.
} 
While industry and government operated with 'business as usual' relations, campaigners began to mobilize collectively to voice their discontent but avoided making the consultation the point of contact to articulate their grievances. In DOC terms this represented an identity shift. This was perceived by industry as a threat, which led to attempts at countermobilization, producing competition around the issue.

Part of this competition included a reframing process that facilitated and was facilitated by the introduction of additional protest groups into the campaign. Specifically, Stewart, using research tying aviation to increased greenhouse gas emissions, was able to convince direct action activists, with whom he was networked previously through the campaign group Transport 2000, to join the campaign. The groups' media stunts led to increased awareness of climate change as a major concern regarding the third runway and this new frame then made recruitment easier. As the frame attracted direct action activists ranging from Greenpeace to Climate Camp, the additional resources that this recruitment provided led to direct confrontation with other actors; it was largely these new actors' interpretations of others that led to a convergence where government and industry were portrayed as collaborators.

The additional resources brought into the campaign were important but are not addressed in the DOC mechanism schema. While McAdam et al. (2001) place 'resource depletion' within the realm of environmental mechanisms, this refers to 'externally generated' changes to resources rather than those that are products of the movement. Additional resources that were brought into the campaign against the Heathrow third runway contributed to expanding the repertoires of contention, and shifted the predominant relations between actors. Here, the amorphous nature of the campaign meant that the increased activities of individual groups that use particular repertoires could determine the predominant relation and set forth a domino effect of interactions. This supports the DOC argument that processes of such events are not composed centrally of 'deliberate strategic decisions' but resemble dynamic processes across various actors (McAdam et al. 2001, 15).

Public attention spread when more confrontation occurred and the campaign received additional support from the public and from other institutions. This was interpreted as the building of momentum, which did not promote continuity of action on the part of campaigners but led to a divergence of interactions. With the public on their side, campaigners felt they could make gentle requests of more sympathetic figures within the aviation industry. Increased support from local constituencies and political parties meant that non-confrontational relations could also be fostered. This latter point was crucial because, as sympathies developed among policymakers, political competition began to increase around the issue. Once the Conservative Party effected its policy U-turn, relations were repoliticized, leading the industry to attack the Conservatives, and campaigners to concentrate on the Labour Party. The causal process for the U-turn was long, involving internal calculations by the Conservative leadership. Interestingly, while polls had not shown that the environment and climate change were particularly salient public issues, the Conservatives still decided to green their image, which played an important role in their U-turn 
(Nulman 2015), thus giving further support for the role of the cognitive mechanism type. Once the polls showed that the re-election of a Labour government was unlikely, campaigners continued to engage in festive action that was less confrontational than in previous phases.

The importance of the cognitive mechanism type was quite evident in influencing interaction between actors throughout the campaign. While the interpretive element of the dynamics of contention was supported in this analysis of interactions within a campaign, traditional social movement theories also made some explanatory contribution. Resource mobilization could be used to explain a move to direct confrontation, while the political process approach can help explain the transition to the repoliticization of relations in mid-2008. In addition, the campaign leadership was also shown to be particularly important in influencing many changes in actors' interactions, echoing Ganz's (2004) perception of strategic capacity and leadership as resources in themselves, and suggesting that deliberate strategic decisions are still of great importance to a campaign.

\section{Conclusion}

I have utilized process tracing as a means to understand the dynamic relations between industry actors and social movements on the issue of environmental policymaking. Specifically I focused

on airport expansion at Heathrow, a case selected because of the significant political power and influence of the main industry actors (BAA and British Airways) in aviation policy. I have highlighted the subjective nature of strategic decision-making and the interpretive nature of contentious manoeuvring when looking at the mechanisms that help to understand changes in relations between actors, demonstrating that dynamic relations occur even amongst antagonistic actors.

While McAdam et al. used a dynamic approach to understand mobilization and outcomes, developing knowledge of the interactions between actors during the course of a campaign can also be of value, not least because $D O C$ identified relations as playing a central role in the process. The central aspects of actor interactions were marked by the seven phases I have outlined. Campaigners initially ignored industry, relying on the government to mediate the conflict, and later blamed the government while expanding their network and developing its message. Campaigners attacked the industry alongside the state, and then asked other industry representatives for support. The industry and the campaign also had varied interactions with policymakers and publics. The mechanisms that explained changes in interactions over time largely support the social constructionist approach of $D O C$, with actors' interpretations of meanings and information playing a crucial role.

Although more case studies and analyses are required to enable us to understand the relative importance of static and dynamic models regarding mobilization, interaction and outcome, I have highlighted the variation of interactions that are exhibited between actors within a contentious environmental campaign. The significant shift in interactions on a variety of 
occasions throughout the campaign suggests that these are normal processes of contention, and that such shifts are products of interpretations of the behaviour of other actors. These shifts occur within the cycle of contention while at the same time they are influenced by more static variables highlighted by the political process and resource mobilization approaches.

The Heathrow case is of particular interest due to its significance for the formation of environmental policies. If relatively radical policy change is possible when policy windows are open (Carter and Jacobs 2013; also see Pralle 2009), it is also worth applying this dynamic analysis to the wider effects of interactions in opening, closing and determining the duration of policy windows. When policy windows are closed, pressure groups may exact smaller changes from policymakers, at a time when dynamic interactions between actors may be even more nuanced and even more crucial. During the contention over Heathrow, an environmental policy window was open, and for considerably longer than is usual for such openings (Carter and Jacobs 2013). It is possible then that interactions between the actors involved helped to keep the policy window open, and that one consequence of their doing so was to provide opportunities that could be exploited to secure the subsequent adoption of other environmental measures, such as the Green Investment Bank (Nulman, 2015), that might otherwise have been obstructed.

\section{References}

AirportWatch, 2013. Responding to the Airports Commission's interim announcement, campaigners vow to fight any expansion at Heathrow and at Gatwick [online]. Available from: http://www.airportwatch.org.uk/2013/12/18886/ [Accessed 17 December 2013].

Boon, B., Davidson, M., Faber, J., Nelissen, D., and van de Vreede, G., 2008. The economics of Heathrow expansion: Final Report [online]. HACAN. Available from: http://www.hacan.org.uk/resources/reports/4504.final.report.pdf [Accessed 05 May 2014].

Boudet, H.S., 2011. From NIMBY to NIABY: regional mobilization against liquefied natural gas in the United States. Environmental Politics, 20(6), 786-806.

Brady, H. E. and Collier, D.C. (eds.), 2004. Rethinking Social Inquiry: Diverse Tools, Shared Standards, Lanham: Rowman and Littlefield.

Butcher, L., 2014. Aviation: London Heathrow Airport. House of Commons Library: SN1136.

Campaign Against Climate Change, 2009. Protestors to target Brown in protest against Heathrow expansion [online]. Available from: http://www.campaigncc.org/sites/data/files/heathrowdemofeb2009.doc [Accessed 15 April 2014]. 
Carter, N. and Jacobs, M., 2014. Explaining Radical Policy Change: The Case of Climate Change and Energy Policy under the British Labour Government 2006-10. Public Administration, 92(1), 125-141.

chiswickw4.com, 2002. Hundreds Turn Out For Anti-Third Runway Protest. chiswickw4.com [online]. Available from:

http://www.chiswickw4.com/default.asp?section=info\&page=evhacan1.htm [Accessed 5 May 2014].

Clasper, M., 2006. Air passengers must cover the cost of carbon emissions. The Guardian, 5 April [online]. Available from: http://www.guardian.co.uk/society/2006/apr/05/guardiansocietysupplement9 [Accessed 28 April 2014].

Doherty, S., 2008. Heathrow's Terminal 5: History in the Making, Wiley: Chichester.

Fligstein, N. and McAdam, D., 2011. Toward a General Theory of Strategic Action Fields. Sociological Theory, 29(1), 1-26.

Friends of the Earth, 1997. "enough is enough mr Prescott" as t5 inquiry enters third year [online]. Available from: https://www.foe.co.uk/resource/press_releases/19970715192351 [Accessed 15 April 2014].

Friends of the Earth, 1998. "Three in a Bed" Scandal at Heathrow Hotel. FoE Exposes Cosy Times at Mammoth Terminal 5 Inquiry [online]. Available from:

http://www.foe.co.uk/resource/press_releases/0515t5 [Accessed 15 April 2014].

Ganz, M., 2004. Why David Sometimes Wins: Strategic Capacity in Social Movements, In: J. Goodwin and J M. Jasper, eds. Rethinking Social Movements: Structure, Meaning and Emotion. Lanham MD: Rowman \& Littlefield Publishers, 177-198.

Geoghegan, T., 2002a. Heathrow protesters vent anger. BBC News, 20 September [online]. Available from: http://news.bbc.co.uk/1/hi/england/2271730.stm [Accessed 5 May 2014].

Geoghegan, T., 2002b. Runway will kill our village. BBC News, 16 October [online]. Available from: http://news.bbc.co.uk/1/hi/england/2334195.stm [Accessed 5 May 2014].

George, R., 2008. The runway steamroller. The Guardian, 27 February [online]. Available from: http://www.guardian.co.uk/commentisfree/2008/feb/27/therunwaysteamroller [Accessed 28 April 2014.

George, A.L. and Bennett, A. 2005. Case Studies and Theory Development in the Social Sciences, Cambridge: MIT Press. 
Gourlay, C. and Ungoed-Thomas, J., 2009. BAA to give up on third Heathrow runway. The Sunday Times, 11 October.

Graham, A., 2008. Airport Planning and Regulation in the United Kingdom. In: C. Winston and G. de Rus, eds. Aviation Infrastructure Performance: A Study in Comparative Political Economy. Washington D.C., The Brookings Institution, 100-135.

Greenpeace, 2007. Greenpeace gives away free train tickets at airports across the UK [online]. Available from: http://www.greenpeace.org.uk/blog/climate/greenpeace-sets-up-climate-ticketexchanges-across-the-uks-airports-20070619 [Accessed 11 May 2014].

Greenpeace, 2008a. Clean graffiti hits London streets [online]. Available from: http://www.greenpeace.org.uk/blog/climate/clean-grafitti-hits-london-streets20080204 [Accessed 11 May 2014].

Greenpeace, 2008b. Climate campaigners bring protest to Heathrow [online]. Available from: http://www.greenpeace.org.uk/media/press-releases/climate-campaigners-bring-protest-toheathrow-20080225 [Accessed 11 May 2014].

Greenpeace, 2008c. Heathrow's Terminal 5 gets flashmobbed [online]. Available from: http://www.greenpeace.org.uk/blog/climate/t5-gets-flash-mobbed-20080327 [Accessed 11 May 2014].

Greenpeace, 2008d. Make a Noise [online]. Available from: http://www.greenpeace.org.uk/blog/climate/make-a-noise-20080408 [Accessed 11 May 2014].

Greenpeace, 2010. Campaigners visit Downing Street to thank Cameron and Clegg for runway cancellation [online]. Available from: http://www.greenpeace.org.uk/media/pressreleases/campaigners-visit-downing-street-thank-cameron-and-clegg-runway-cancellation20100513 [Accessed 7 October 2014].

HACAN, 1995. Opening Statement to the Public Inquiry into a Fifth Terminal at Heathrow by the Chairman of HACAN, Dermot Cox, Tuesday 16th May 1995 [online]. Available from: http://www.hacan.org.uk/resources/consultation_responses/hacan.5th_terminal.opening.pdf [Accessed 15 April 2014].

HACAN ClearSkies, 2003a. Direct action protesters disrupt work on Terminal 5 site [online]. Available from: http://www.hacan.org.uk/news/press_releases.php?id=50 [Accessed 15 April 2014].

HACAN ClearSkies, 2003b. 3rd Runway Protesters to Demonstrate Outside British Airways AGM in Colourful Stunt [online]. Available from: http://www.hacan.org.uk/news/press_releases.php?id=49 [Accessed 11 May 2014]. 
HACAN ClearSkies, 2005a. Appointment of British Airways chief to advise ministers "cements links between the aviation industry and government" [online]. Available from:

http://www.hacan.org.uk/news/press_releases.php?id=112 [Accessed 11 May 2014].

HACAN ClearSkies, 2005b. Angry residents give Rod Eddington a taste of his own medicine [online]. Available from: http://www.hacan.org.uk/news/press_releases.php?id=121 [Accessed 11 May 2014].

HACAN ClearSkies, 2006. Future Heathrow's Arguments Flounder in Face of Chamber of Commerce Survey [online]. Available from:

http://www.hacan.org.uk/news/press_releases.php?id=147 [Accessed 11 May 2014].

HACAN ClearSkies, 2007. Direct Action: West London residents halt traffic outside Department for Transport Headquarters [online]. Available from:

http://www.hacan.org.uk/news/press_releases.php?id=183 [Accessed 11 May 2014].

HACAN ClearSkies, 2009. Mandelson Revelations Increase Pressure on Government over Third Runway [online]. Available from: http://www.hacan.org.uk/news/press_releases.php?id=241

[Accessed 11 May 2014].

HACAN Clearskies, n.d. If Heathrow fails to grow, it will go the way of London's docks?. http://www.hacan.org.uk/resources/reports/hacan.countering.future.heathrow.arguments.pdf [Accessed 15 April 2014].

Haifacree, K., 2001. Take-off for an environmental disaster. The Guardian, 27 June [online]. Available from: http://www.guardian.co.uk/theguardian/2001/jun/27/guardianletters3 [Accessed 27 April 2014].

Heaney, M.T. and Rojas, F., 2011. 'The Partisan Dynamics Of Contention: Demobilization Of The Antiwar Movement In The United States, 2007-2009', Mobilization, 16(1), 45-64.

Heathrow Consultation Rally, 2008. [online]. Alankeen.com. Available from:

http://www.alankeen.com/4136a6d7-9c8d-d154-cd5b-d17e086d90ef [Accessed 5 July 2012].

Hedström, P. and Swedberg, R., 1998. Social Mechanisms: An Analytical Approach to Social Theory. Cambridge: Cambridge University Press.

Hilson, C., 2010. Climate Change Litigation: A Social Movement Perspective. Legal and Criminological Consequences of Climate Change. Ontani, Spain, 29-30 April.

den Hond, F. and de Bakker, F.G.A., 2007. Ideologically Motivated Activism: How Activist Groups Influence Corporate Social Change Activities, Academy of Management Review, 32(3), 901-924. 
Indymedia UK, 2007. Day 6: Climate Camp's 24 Hours of Direct Action, Indymedia UK, 19 August http://www.indymedia.org.uk/en/2007/08/378854.html [Accessed 15 April 2014].

Juniper, T., 2008. Virgin territory. The Guardian, 25 February [online]. Available from: http://www.guardian.co.uk/commentisfree/2008/feb/25/virginterritory [Accessed 05 May 2014].

Lewis, P., 2009. Festival-goers spell out runway feelings. The Observer, 28 June [online]. Available from: http://www.guardian.co.uk/music/2009/jun/28/glastonbury-greenpeaceheathrow-third-runway [Accessed 07 May 2014].

McAdam, D., Tarrow, S., and Tilly, C., 2001. Dynamics of Contention. New York: Cambridge University Press.

McCarthy, J., and Zald, M.N., 1977. Resource Mobilization and Social Movements: A Partial Theory, American Journal of Sociology, 82, 1212-1241.

Michels, R. 1915. Political Parties. A Sociological Study of the Oligarchical Tendencies of Modern Democracy. New York: Hearst's International Library Co.

Milmo, D., 2008a. Walsh attacks Cameron over airport expansion. The Guardian, 26 June [online]. Available from:

http://www.guardian.co.uk/business/2008/jun/26/theairlineindustry.britishairwaysbusiness [Accessed 28 April 2014].

Milmo, D., 2008b. Airline industry slams Tory plans to scrap third runway. The Guardian, 29 September [online]. Available from:

http://www.guardian.co.uk/business/2008/sep/29/britishairways.baa [Accessed 29 April 2014].

Milmo, D., 2008c. Aviation: Half price oil, cheaper tickets - report sees flaws in case for third Heathrow runway. The Guardian, 23 July [online]. Available from:

http://www.guardian.co.uk/environment/2008/jul/23/activists.baa [Accessed 28 April 2014].

Milmo, D., 2009a. Heathrow third runway plans dealt massive blow. The Guardian, 27 March [online]. Available from: http://www.guardian.co.uk/politics/2009/mar/27/heathrow-thirdrunway-threat [Accessed 07 May 2014].

Milmo, D., 2009b. Tory block on third Heathrow runway a big mistake, says British Airways chief. The Guardian, 8 December [online]. Available from:

http://www.guardian.co.uk/uk/2009/dec/08/tory-block-heathrow-runway-ba [Accessed 07 May 2014].

Murray, L., 2007. Diary of a protest. Index on Censorship, 36, 22-39.

NoTRAG, 2005. BAA: "time to come clean about your new tenants" [online]. Available from: http://www.notrag.org/pdf/NoTraGPressRelease-30May2005.pdf [Accessed 11 May 2014]. 
NoTRAG, 2009. Campaigners have a Big Lunch on site of third runway [online]. Available from: http://www.notrag.org/archive/July\%202009.php\#july2 [Accessed 11 May 2014].

Nulman, E., 2015. Climate Change and Social Movements: Civil Society and the Development of National Climate Change Policy. Basingstoke and New York: Palgrave Macmillan.

Olson, M. Jr., 1965. The Logic of Collective Action. Cambridge: Harvard University Press. Plane Stupid, 2007a. Protestors take direct action to blockade BAA Headquarters [online]. Available from: http://www.planestupid.com/blogs/2006/04/3/protesters-direct-action-blockadebaa-headquarters [Accessed 11 May 2014].

Plane Stupid, 2007b. Plane Stupid disrupt Parliamentary Committee into "Future of BAA" [online]. Available from: http://www.planestupid.com/?q=content/plane-stupid-disruptparliamentary-committee-future-baa [Accessed 28 April 2014].

Plane Stupid, 2007c. Angry Heathrow residents disrupt Ministers speech [online]. Available from: http://www.planestupid.com/blogs/2007/02/12/angery-heathrow-residents-disruptministers-speech [Accessed 11 May 2014].

Plane Stupid, 2009a. Plane Stupid turf Virgin Atlantic out of their seats at the PR awards [online]. Available from: http://www.planestupid.com/blogs/2009/10/21/plane-stupid-turf-virginatlantic-out-their-seats-pr-awards [Accessed 11 May 2014].

Plane Stupid, 2009b. Heathrow campaigners storm Architect Awards to warn off third runway bids [online]. Available from: http://www.planestupid.com/blogs/2009/11/6/heathrowcampaigners-storm-architect-awards-warn-third-runway-bids [Accessed 11 May 2014].

Plane Stupid, 2014. Back to the Heathrow barricades as government get ready for an airport uturn [online]. Available from: http://www.planestupid.com/blogs/2014/01/6/back-heathrowbarricades-government-get-ready-airport-u-turn [Accessed 6 January 2014].

Pralle, S. B., 2009. Agenda-setting and climate change. Environmental Politics, 18(5), 781-799. Richmond \& Twickenham Times, 2003. Heathrow crane top protest. Richmond \& Twickenham Times, 10 October [online]. Available from: http://www.richmondandtwickenhamtimes.co.uk/news/421501.print/ [Accessed 15 May 2014].

Rikki, 2005. Critical mass lock-on at aviation conference at Tower Bridge tonight [online]. Available from: http://www.indymedia.org.uk/en/2005/11/328781.html [Accessed 11 May 2014].

Rootes, C., 2013. From local conflict to national issue: when and how environmental campaigns succeed in transcending the local. Environmental Politics, 22(1), 95-114. 
Saunders, C., 2004. Collaboration, Competition and Conflict: Social Movement and Interaction Dynamics of London's Environmental Movement. PhD Thesis, School of Social Policy, Sociology and Social Research, University of Kent, Canterbury.

Saunders, C. and Price, S., 2009. One person's eu-topia, another's hell: Climate Camp as a heterotopia. Environmental Politics, 18(1), pp. 117-122.

Schlembach, R., Lear, B. and Bowman, A., 2012. Science and ethics in the post-political era: strategies within the Camp for Climate Action. Environmental Politics, 21(5), pp. 811-828.

SchNEWS, 2005. .... and finally... [online]. Available from:

http://www.schnews.org.uk/archive/news499.htm [Accessed 11 May 2014].

Schneiberg, M., King, M. and Smith, T., 2008. Social Movements and Organizational Form: Cooperative Alternatives to Corporations in the American Insurance, Dairy, and Grain Industries. American Sociological Review, 73, 635-667.

Schurman, R., 2004. Fighting "Frankenfoods": Industry Opportunity Structures and the Efficacy of the Anti-Biotech Movement in Western Europe, Social Problems, 51(2), 243-268.

Soley, C., 2005. Former MP explains the role of Future Heathrow [online]. Available from: http://nnet-server.com/server/common/consoley08.htm [Accessed 15 May 2014].

Stewart, J., 2010. Victory against All the Odds. Nottingham: Russell Press Ltd.

Stewart, J., 2012. Heathrow's third runway is not happening - move on. The Guardian, 27 March [online]. Available from: http://www.guardian.co.uk/commentisfree/2012/mar/27/heathrow-third-runway-not-happening [Accessed 17 May 2014].

Vidal, J., 2009. Heathrow airport expansion threatened by legal challenge. The Guardian, 7 April [online]. Available from: http://www.guardian.co.uk/environment/2009/apr/07/heathrow-thirdrunway-expansion-legal-challenge [Accessed 17 May 2014].

Walsh, W., 2008. Be realistic about Heathrow expansion. The Guardian, 15 December [online]. Available from: http://www.guardian.co.uk/commentisfree/2008/dec/15/theairlineindustryheathrow [Accessed 17 May 2014].

WWF-UK, n.d. Heathrow legal challenge [online]. Available from: http://www.wwf.org.uk/what_we_do/campaigning/one_planet_mobility/heathrow_legal_challen ge.cfm [Accessed 11 May 2012].

van der Zee, B., 2009. Climate Rush - time to get on your high horse and cart. The Guardian [online]. Available from: http://www.guardian.co.uk/environment/blog/2009/sep/04/climaterush-horse-cart [Accessed 17 May 2014]. 
